Jurnal Pendidikan Matematika : Judika Education

Volume 2, Nomor 2, Juli-Desember 2019

e-ISSN : 2614-6088

p-ISSN : 2620-732X

DOI : https://doi.org/10.31539/judika.v2i2.857

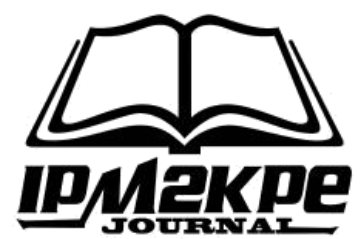

\title{
IDENTIFIKASI KONSEP MATEMATIKA MELALUI AKTIVITAS ETNOMATEMATIKA PETANI SAWAH
}

\author{
Laksmi Aulia ${ }^{1}$, Lia Rista ${ }^{2}$ \\ STKIP Bumi Persada Lhokseumawe 1,2 $^{1,2}$ \\ laksmiaulia@ymail.com ${ }^{1}$
}

\begin{abstract}
ABSTRAK
Tujuan penelitian ini adalah untuk mengetahui konsep matematika melalui aktivitas etnomatematika petani sawah pada masyarakat di desa Blang Jrun Aceh Utara. Penelitian ini merupakan jenis penelitian kualitatif dengan pendekatan etnografi. Subjek penelitian ini sebanyak 8 orang yang berprofesi sebagai petani di Desa Blang Jruen Kabupaten Aceh Utara. Metode Pengumpulan data yang digunakan adalah wawancara, dokumentasi dan observasi. Hasil penelitian menunjukan bahwa petani masyarakat di Desa Blang Jruen secara tidak langsung telah menggunakan aktifitas etnomatematika dalam kegiatan bertani sawah. Aktivitas etnomatematika yang digunakan meliputi aktivitas membilang, menghitung dan mengukur. Aktivitas yang paling sering muncul pada petani sawah adalah aktivitas menghitung. Pada aktifitas menghitung banyak muncul konsep-konsep matematika yang dilakukan para petani. Seperti penjumlahan; pengurangan; perkalian; pembagian; perbandingan senilai; dan perbandingan berbalik nilai. Sedangkan aktivitas membilang hanya muncul pada penyebutan luas sawah. Aktivitas mengukur muncul ketika memperkirakan jarak antara tanaman yang satu dan yang lain serta memperkirkan ukuran luasa sawah dan hasil panen. Simpulan, terdapat banyak aktifitas etnomatematika dalam kegiatan bertani yang dilakukan oleh masyarakat Desa Blang Jruen Kabupaten Aceh Utara, ktifitas etnomatematika tersebut meliputi aktifitas membilang, menghitung dan mengukur. Konsep-konsep tersebut dapat dijadikan bahan inspirasi dan bahan rujukan pembelajaran kontekstual.
\end{abstract}

Kata Kunci : Aktivitas Etnomatematika, Konsep Matematika, Petani Sawah

\begin{abstract}
The purpose of this study was to determine the mathematical concepts through ethnomatematics activities of rice farmers in the community in Blang Jrun village, North Aceh. This research is a type of qualitative research with an ethnographic approach. The subjects of this study were 8 people who work as farmers in Blang Jruen Village, North Aceh Regency. Data collection methods used were interviews, documentation and observation. The results showed that community farmers in Blang Jruen Village indirectly used ethnomatematics activities in rice farming. Ethnomatematic activities used include counting, counting and measuring activities. The most common activity in rice farmers is counting activity. In counting activities many mathematical concepts emerge by the farmers. Like addition; reduction; multiplication; division; worth comparison; and the comparison turned value. Whereas the spelling activity only appears in
\end{abstract}


the mention of the vast rice fields. Measuring activity arises when estimating the distance between one crop and another and estimating the size of rice fields and yields. Conclusion, there are a lot of ethnomatematics activities in farming activities carried out by the Blang Jruen Village community in North Aceh Regency. Ethnomatematics activities include counting, counting and measuring activities. These concepts can be used as inspiration and contextual learning reference material.

Keywords: Ethnomatematics Activities, Mathematical Concepts, Rice Farmers

\section{PENDAHULUAN}

Matematika merupakan ilmu pengetahuan yang memiliki peranan sangat penting dalam menghadapi berbagai tantangan kehidupan. Matematika juga menjadi dasar bagi perkembangan ilmu pengetahuan yang lain, seperti dijelaskan NCTM (2000) bahwa "mathematics is used in science, the social science, medicine and commerce". Selain itu, Matematika memiliki peran baik dalam berbagai budaya, tepatnya pada kebiasaan suatu kelompok masyarakat dalam hal adat istiadatnya. Namun masyarakat kurang menyadari bahwa sebagian aktivitas yang dilakukan terdapat aktivitas-aktivitas matematika. Bahkan mereka terkadang juga masih bingung dalam menggunakan konsep matematika yang dipelajari di bangku sekolah untuk diterapkan dalam kehidupan sehari-hari (D'Ambrosio, U,1985).

Dalam kehidupan sehari-hari, matematika dipakai untuk menghitung, menalar atau memecahkan masalah. Sebagai contoh, pada transaksi jual-beli digunakan konsep aritmatika sosial, bentuk bangunan gedung perkantoran yang berhubungan dengan geometri, permainan catur yang menggunakan konsep translasi, dan menanam padi di sawah yang berhubungan dengan konsep barisan aritmatika (Fadlilah et al, 2015).

Keterkaitan antara matematika dan budaya dikenal sebagai etnomatematika. Etnomatematika di Indonesia sebenarnya bukanlah merupakan suatu ilmu pengetahuan baru melainkan sudah dikenal sejak lama dan diperkenalkan ilmuwan matematika itu sendiri. Hanya saja disiplin ilmu ini disadari setelah beberapa ilmuwan memperkenalkan nama etnomatematika menjadi bagian dari ilmu matematika. Sejak dikenal secara luas, etnomatematika mulai dikembangkang melalui kajian berbagai keilmuan yang relevan (Rosa \& Orey, 2011).

Ngiza et al. (2015)

mengungkapkan bahwa Etnomatematika merupakan salah satu ilmu matematika yang berkaitan dengan aktivitas masyarakat dalam kehidupan sehari-hari pada suatu kelompok budaya tertentu. Aktivitas masyarakat tersebut seperti aktivitas menghitung, mengukur, dan merancang sebuah bangunan, serta masih banyak aktivitas lainnya.

Hasil penelitian Friansyah \& Luthfiana (2018) menyatakan pembelajaran Matematika yang berkualitas harus didukung berbagai aspek, satu diantara aspek yang utama adalah guru profesional yang mampu memanfaatkan berbagai 
sumber belajar dan mengembangkan bahan ajar (LKS) dengan memanfaatkan konteks budaya sehari-hari (etnomatematika) yang dialami siswa.

Pada penelitian ini, daerah yang dipilih oleh peneliti adalah daerah Aceh Utara tepatnya di Desa Blang Jrun. Sedangkan aktivitas yang dipilih pada penelitian ini adalah aktivitas para petani yang meliputi aktivitas membilang, menghitung, dan mengukur. Hal tersebut dikarenakan mayoritas penduduk desa berprofesi sebagai petani dan sekalipun diantara mereka ada yang memiliki pendidikan yang rendah, tetapi mereka dapat menggunakan matematika dengan cara mereka sendiri.

\section{METODE PENELITIAN}

Jenis penelitian yang digunakan adalah penelitian kualitatif dengan pendekatan etnografi. Moleong (2012) mengatakan bahwa Penelitian kualitatif adalah penelitian yang bermaksud untuk memahami fenomena tentang apa yang dialami oleh subjek penelitian misalnya perilaku, persepsi, motivasi, tindakan, dan lain-lain. Sedangkan pendekatan yang digunakan dalam penelitian ini adalah pendekatan etnografi. yaitu pendekatan empiris dan teoritis yang bertujuan mendapatkan deskripsi dan analisis mendalam tentang kebudayaan berdasarkan penelitian lapangan (fieldwork) yang intensif.

Penelitian ini dilakukan di

Balai Desa Blang Jrun dan lingkungan sekitar Desa Blang Jrun Aceh Utara. Waktu penelitian ini dilakukan dari bulan Juni sampai Agustus 2018.
Subjek penelitian yang digunakan adalah masyarakat di Desa Blang Jrun yang berprofesi sebagai petani padi. Subjek penelitian tersebut ditetapkan berdasarkan teknik snowball sampling. Dalam penelitian ini subjek penelitian yang diambil sebanyak 8 petani padi yang merupakan masyarakat Desa Blang Jrun Aceh Utara. Instrumen penelitian yang digunakan dalam penelitian ini adalah :

\section{Wawancara}

Wawancara dilakukan secara wawancara semi terstuktur. Tujuan dari wawancara jenis ini adalah untuk menemukan permasalahan secara lebih terbuka, dimana pihak yang diajak wawancara diminta pendapat, dan ide-idenya. Dalam melakukan wawancara, penelitian perlu mendengarkan secara teliti dan mencatat apa yang dikemukakan oleh informan. Pedoman wawancara ini berisi pertanyaan-pertanyaan yang ditanyakan penulis untuk memperkuat hasil dari pengumpulan data yang dilakukan dengan metode dokumentasi serta catatan lapangan.

\section{Dokumentasi}

Dokumentasi dalam penelitian ini berupa data-data dalam bentuk dokumen tentang aktivitasi etnomatematika petani sawah . Metode dokumentasi adalah teknik pengumpulan data yang tidak langsung ditujukan pada subyek penelitian, namun melalui dokumen. Dokumen yang digunakan dapat berupa buku harian, surat pribadi, catatan khusus dalam kegiatan sosial dan dokumen lainnya. 


\section{Observasi}

Observasi dari penelitian ini adalah observasi langsung mengenai konsep matematika melalui aktivitas etnomatematika petani sawah. Observasi adalah cara menghimpun bahan-bahan yang dilakukan dengan mengadakan pengamatan dan pencatatan secara sistematis terhadap fenomena yang sedang disajikan.

\section{HASIL PENELITIAN}

Hasil penelitian menunjukkan bahwa etnomatematika masih banyak digunakan oleh masyarakat Desa Blang Jruen Kabupaten Aceh Utara terutama oleh petani padi, berbagai perhitungan dan penggambaran etnomatematika antara lain simbol untuk menentukan luas, menghitung luas sawah, menentukan jarak antara benih padi, menghitung banyak benih yang diperlukan dan menghitung hasil panen yang diperoleh petani saat musim panen. Masih ada petani di Desa Blang Jruen Kabupaten Aceh Utara yang dengan sederhana melestarikan budaya mereka. Para petani tidak terikut oleh kemajuan dan perkembangan zaman.

Desa Blang Jruen merupakan salah satu yang terletak di wilayah Kecamatan Tanah Luas, Kabupaten Aceh Utara dengan Luas wilayah 167 $\mathrm{Ha}$ dengan batas-batas wilayah Gampong sebagai berikut :
1. Sebelah Utara :Gp.
Serbajaman / Gp. Tgk Di Balee
2. Sebelah Timur :Gp.
Serbajaman / Gp. Rayeuk
Meunye

3. Sebelah Selatan : Gp. Rayeuk Meunye

4. Sebelah Barat : Gp. Keude Blang Jruen
Jarak Desa Blang Jruen dengan Ibu kota Kabupaten $\pm 30 \mathrm{~km}$ dengan jarak tempuh 20 menit menggunakan angkutan umum berupa mobil ataupun sepeda motor.

Kodisi fisik Desa Blang Jruen dapat dilihat dari segi pemanfaatan lahan. Desa Blang Jruen dengan luasnya $167 \mathrm{Ha}$, dalam pemanfaatan lahan adalah sebagai berikut :

1. Luas perkarangan/pemukiman : $143 \mathrm{Ha}$

2. Luas Persawahan : $2 \mathrm{Ha}$

3. Luas Perkebunan : $10 \mathrm{Ha}$

4. Luas Kuburan : $3 \mathrm{Ha}$

5. Rawa-rawa : $2 \mathrm{Ha}$

6. Tanah Kosong : $7 \mathrm{Ha}$

Petani sawah di Desa Blang Jruen Kabupaten Aceh Utara melakukan penanaman padi sebanyak dua kali dalam satu tahun dengan menggunakan metode irigasi. Untuk mendapatkan tanaman padi yang berkualitas, tentu diperlukan proses penanaman padi yang baik dan benar. Berikut ini beberapa langkah dalam cara menanam padi, yaitu :

\section{Persiapan media tanam}

Petani sawah di Desa Blang Jruen Kabupaten Aceh Utara menyiapkan minimal dua minggu sebelum penanaman untuk persiapan media tanam. Persiapan dilakukan dengan cara mengolah tanah sebagai media tanam. Tanah harus dipastikan bebas dari gulma, rumput dan tanaman liar. Jika sudah bebas dari tanaman liar, basahi tanah dengan air lalu lakukan pembajakan. Di zaman modern ini pembajakan tidak lagi dilakukan dengan mencangkul tetapi dengan menggunakan sapi ataupun traktor. Setelah melalui pembajakan, kembali genangi media tanam dengan air. Air diberikan dalam jumlah 
banyak untuk menutupi seluruh lahan dengan ketinggian hingga $10 \mathrm{~cm}$. Biarkan air pada media tanam terus menggenang. Air yang menggenang selama dua minggu akan menyebabkan media tanam menjadi berlumpur dan racun pun dapat hilang karena ternetralisir. Petani sawah di Desa Blang Jruen menggunakan metode irigasi untuk mengairi sawah mereka. Dengan begitu, petani sawah tidak mengandalkan musim hujan.

\section{Pemilihan bibit}

Bibit pada tanaman padi harus melalui pengujian terlebih dahulu untuk menentukan kualitasnya. Pengujian dapat dilakukan dengan cara merendam sekitar 100 butir benih padi dalam air. Selanjutnya setelah dua jam, periksalah benih tersebut. Cara memilih benih padi yaitu dengan cara mengidentifikasi perubahan pada benih. Jika terdapat lebih dari $90 \%$ benih mengeluarkan kecambah, artinya benih tersebut berkualitas unggul dan bermutu tinggi. Tentu benih yang berkualitas unggul dan bermutu tinggi yang layak untuk dibudidayakan. Sedangkan jika benih tidak menunjukkan tanda berkecambah, artinya benih tersebut tidak disarankan untuk dibudidayakan. Setelah menentukan benih yang akan dijadikan bibit, maka dapat dilakukan persemaian bibit.

\section{Persemaian bibit}

Persemaian dilakukan setelah menentukan bibit yang berkualitas unggul dan bermutu tinggi. Bibit yang berkualitas unggul disemai di wadah persemaian. Langkah-langkah yang dilakukan petani sawah di Desa Blang Jruen Kabupaten Aceh Utara dalam persemaian bibit yaitu : (1) dilakukan perendaman selama 24 jam; (2) memasukkan kedalam empang selama 72 jam; (3) ditaburkan dalam neduk selama 15-18 hari (4) dipindahkan ke lokasi penanaman padi. Proses pembibitan padi dilakukan selama 3-4 minggu, setelah proses pembibitan selesai maka masuk tahap penanaman.

\section{Penanaman}

Proses penanaman padi dilakukan setelah benih pada proses persemaian telah tumbuh daun sempurna sebanyak tiga sampai empat helai. Pemindahan dilakukan dengan hati-hati dan tidak merusak tanaman. Penanaman dilakukan pada lubang-lubang tanam yang telah disiapkan. Khusus untuk tanaman padi dalam satu lubang dapat ditanam dua bibit sekaligus. Kedalaman bibit ditanam pun ditentukan berkisar pada rentang $5 \mathrm{~cm}$ hingga $10 \mathrm{~cm}$. Masyarakat Desa Blang Jruen Kabupaten Aceh Utara yang memiliki lahan sawah ada yang menggunakan buruh untuk proses penanaman padi. Upah yang diberikan untuk 1 petak sawah berikisar Rp. 50.000,- / orang untuk setengah hari yang dikerjakan oleh 6-8 orang.

\section{Perawatan Lahan}

Perawatan dilakukan dengan tiga hal yaitu penyiangan, pengairan, dan pemupukan. Penyiangan dilakukan dengan menjaga kebersihan lahan dari tanaman liar pengganggu. Penyiangan harus dilakukan secara rutin setiap periode waktu tertentu. Misalnya, dilakukan dua minggu sekali atau tiga minggu sekali. Pengairan diberikan sesuai kebutuhan. Seperti pada tanaman lainnya, pastikan tidak ada 
kekurangan atau kelebihan air. Selanjutnya untuk pemupukan, dilakukan pertama kali setelah tanaman padi berusia satu minggu. Jenis pupuk yang diberikan adalah pupuk urea dengan dosis $100 \mathrm{~kg}$ per hektar dan pupuk TPS dengan dosis $50 \mathrm{~kg}$ per hektar. Pemupukan selanjutnya dilakukan setelah 25 hari hingga 30 hari setelah penanaman. Diberikan kembali pupuk urea dengan dosis $50 \mathrm{~kg}$ per hektar dan pupuk Phonska dengan dosis $100 \mathrm{~kg}$ per hektar.

\section{Pemanenan}

Panen dilakukan dengan tanda-tanda padi yang sudah menguning dan merunduk. Alat yang digunakan adalah sabit gerigi untuk memanen dan letakkan hasil panen pada tikar dengan merontokkan beras dari dalam bulir-bulir padi yang ada. Akan tetapi, ada juga petani yang menggunakan alat bantu mesin potong dan menggunakan mesin rontok padi untuk menghemat waktu agar pekerjaan cepat selesai.

\section{PEMBAHASAN}

Secara rinci ada beberapa aktifitas etnomatematika yang masih banyak digunakan oleh petani sawah di Desa Blang Jruen Kabupaten Aceh Utara yang dijelaskan sebagai berikut.

\section{Aktifitas Membilang}

Aktifitas membilang salah satunya muncul pada saat menyebutkan ukuran luas sawah. Pada saat menyebutkan ukuran luas sawah, petani menggunakan ukuran luas yang berbeda yang hanya berlaku di Desa Blang Jruen Kabupaten Aceh Utara. Setiap daerah memiliki keanekaragaman yang berbeda dalam melestarikan budaya masing-masing. Sedangkan untuk menyebutkan angka, petani sawah di Desa Blang Jruen Kabupaten Aceh Utara menggunakan bahasa Aceh. Ukuran luas yang digunakan diantaranya yaitu.

$$
\begin{aligned}
& 1 \text { mah }=1600 \mathrm{~m}^{2} \\
& 1 \text { gupang }=400 \mathrm{~m}^{2}
\end{aligned}
$$

Selain itu, aktifitas membilang juga muncul pada saat menyebutkan hasil panen padi. Hasil panen padi berhubungan dengan satuan berat yaitu.

$$
\begin{aligned}
& 1 \text { naleh }=20 \mathrm{~kg} \\
& 1 \text { naleh }=16 \text { are } \\
& 1 \quad \begin{array}{l}
\text { mah }=5 \text { bunca }=50 \\
\text { naleh }
\end{array}
\end{aligned}
$$

Tabel 1.

Angka dalam bahasa Aceh

\begin{tabular}{cc}
\hline $\begin{array}{c}\text { Dalam Bahasa } \\
\text { Aceh }\end{array}$ & $\begin{array}{c}\text { Dalam Bahasa } \\
\text { Indonesia }\end{array}$ \\
\hline Noy & Nol \\
\hline Sa & Satu \\
\hline Duwa & Dua \\
\hline Lhèë & Tiga \\
\hline Peuët & Empat \\
\hline Limong & Lima \\
\hline Nam & Enam \\
\hline Tujoh & Tujuh \\
\hline Lapan & Delapan \\
\hline Sikureung & Sembilan \\
\hline Siploh & Sepuluh \\
\hline Duwa Ploh & Dua Puluh \\
\hline Sireutoh & Seratus \\
\hline Siribee & Seribu
\end{tabular}

\section{Aktifitas Menghitung}

Aktifitas menghitung merupakan aktifitas matematika yang paling sering muncul pada kegiatan bertani masyarakat Desa Blang Jruen Kabupaten Aceh Utara. Pada aktifitas ini juga sering ditemukan beberapa konsep matematika yang digunakan 
petani diantaranya : Penjumlahan; Pengurangan; Perkalian; Pembagian; Perbandingan Senilai; dan Perbandingan Berbalik Nilai.

Penjumlahan, petani sawah selalu menghitung biaya pengeluaran yang dilakukan selama proses penanaman dan perawatan padi sampai panen. Disini akan muncul strategi perhitungan operasi penjumlahan yang digunakan petani. Ada dua strategi yang ditemukan, yaitu menghitung dari bilangan terbesar dan menghitung dari bilangan terkecil.

Pengurangan,

operasi pengurangan akan muncul pada saat petani menghitung keuntungan atau kerugian. Jika dalam sistem pertanian harga jual lebih tinggi dari biaya total pengeluaran maka petani akan mengalami keuntungan, konsep yang digunakan adalah dengan cara mengurangkan harga jual petani dan biaya total pengeluaran. Sebaliknya, jika harga jual padi lebih rendah dari pada biaya total pengeluaran maka petani mengalami kerugian. Hal ini dapat kita ketahui dengan hasil dari pengurangan adalah negative yang menunjukkan bahwa petani tersebut mengalami kerugian.

Perkalian, perhitungan perkalian muncul ketika petani membayar upah pada pekerja. Cara perhitungan upah tersebut dengan mengalikan upah per oragn dengan banyaknya pekerja. Pada masyarakat Desa Blang Jruen Kabupaten Aceh Utara besar upah yang diberikan untuk menanam padi sebesar Rp. $50.000,-$ / orang dengan luas sawah 1 mah yang dikerjakan sebanyak 6-8 orang selama $1 / 2$ hari. Artinya, jika sawah tersebut dikerjakan oleh 6 orang maka 6 x Rp. 50.000,- = Rp. 300.000,- .

Pembagian, perhitungan pembagian juga akan tampak pada saat menghitung upah pekerja. Misalnya, 1 petak sawah akan dipanen secara manual dan dikerjakan oleh 3 orang buruh dengan biaya $\mathrm{Rp}$. 240.000,- . Maka untuk menghitung upah yang diterima oleh seorang buruh akan dilakukan perhitungan pembagian yaitu Rp. 240.000,- : 3 orang $=$ Rp. $80.000,-$ / orang.

Perbandingan Senilai, konsep matematika ini muncul ketika petani memperkirakan jumlah benih yang akan ditanam dan jumlah pupuk yang akan diberikan. Melalui ukuran luas sawah, petani dapat menentukan jumlah benih yang akan di tanam dan julah pupuk yang diberikan. Semakin luas sawah yang dimiliki oleh petani, maka jumlah benih dan pupuk yang diperlukan akan semakin banyak. Konsep ini secara tidak sadar sangat sering digunakan oleh petani sawah di Desa Blang Jruen Kabupaten Aceh Utara.

Perbandingan Berbalik Nilai, konsep ini akan muncul pada saat petani memperkirakan waktu yang diperlukan buruh untuk penanaman padi dan memanen padi. Misalnya sebuah petak sawah berukuran $1 \mathrm{mah}$ yang dikerjakan oleh 6 orang buruh akan lebih cepat dibandingkan dengan 4 orang buruh dengan luas sawah yang sama. Sehingga dapat ditarik kesimpulan semakin banyak buruh yang bekerja maka waktu yang diperlukan akan semakin cepat, dan begitu sebaliknya.

\section{Aktifitas Mengukur}

Aktifitas mengukur muncul ketika petani melakukan aktifitas 
menanam padi yang selalu dilakukan dengan cara membuat jalur menanam terlebih dahulu dengan menarik sebuah tali agar jarak tanam antara bibit yang satu dengan yang lainnya sama. Masyarakat Desa Blang Jruen menggunakan ukuran jengkal yang berkisar dengan jarak $20 \mathrm{~cm}$.

\section{SIMPULAN}

Berdasarkan hasil penelitian ini, menunjukkan bahwa terdapat banyak aktifitas etnomatematika dalam kegiatan bertani yang dilakukan oleh masyarakat Desa Blang Jruen Kabupaten Aceh Utara. Aktifitas etnomatematika tersebut meliputi aktifitas membilang, menghitung dan mengukur. Selain itu, pada aktifitas menghitung banyak muncul konsep-konsep matematika yang dilakukan para petani. Seperti penjumlahan; pengurangan; perkalian; pembagian; perbandingan senilai; dan perbandingan berbalik nilai. Dimana konsep-konsep tersebut dapat dijadikan bahan inspirasi dan bahan rujukan pembelajaran kontekstual.

\section{DAFTAR PUSTAKA}

D'Ambrosio, U. (1985). Ethnomathematics and its place in the history and pedagogy of mathematics. For the Learning of Mathematics, 5(1); 44-48.

Fadlilah, U. (2015). Idenifikasi Aktivitas Etnomatematika Petani pada Masyarakat Jawa di Desa Setail. Jurnal Kadikma 6 (3); 45-56.

Friansyah, D., \& Luthfiana, M. (2018). Desain Lembar Kerja Siswa Materi Sistem Persamaan Dua Variabel Berorientasi
Etnomatematika. Jurnal Pendidikan Matematika (JUDIKA EDUCATION), 1(2), 83-92.

https://doi.org/https://doi.org/10 .31539/judika.v1i2.322

Moleong, L., J. (2012). Metodologi Penelitian Kualitatif. Bandung: PT. Remaja Rosdakarya.

NCTM. (2000). Principles and Standards for School Mathematics. United States of America : The National Council of Teachers of Mathematics, Inc.

Ngiza, L., N. (2015). Identifikasi Aktivitas Etnomatematika Petani pada Masyarakat Jawa di Desa Sukareno. Artikel Ilmiah Mahasiswa. 1 (1); 1-6.

Pratama, L., D. \& Lestari, W. (2017). Eksplorasi Etnomatematika Petani dalam Lingkup Masyarakat Jawa. Seminar Nasional Matematika dan Pendidikan Matematika FPMIPATI-Universitas PGRI Semarang.

Rosa, M. \& Orey, D. C. (2011). Ethnomathematics: the cultural aspects of mathematics. Revista Latinoamericana de Etnomatemática, 4(2); 32-54 